\title{
Syphilis in patients of the Department of Dermatology and Venereology at Medical University of Warsaw in 2015 - epidemiological and clinical characteristics, and coexistence of other sexually transmitted diseases
}

\author{
Kiła u pacjentów Kliniki Dermatologii i Wenerologii Warszawskiego Uniwersytetu \\ Medycznego w 2015 r. - charakterystyka epidemiologiczna, kliniczna \\ oraz współistnienie innych chorób przenoszonych drogą płciową
}

\author{
Ewelina Biało-Wójcicka', Beata Młynarczyk-Bonikowska², Anna Winiarska³, Iwona Rudnicka3 \\ Tomasz Pniewski², Aleksandra Komorowska³, Magdalena Malejczyk², Sławomir Majewski

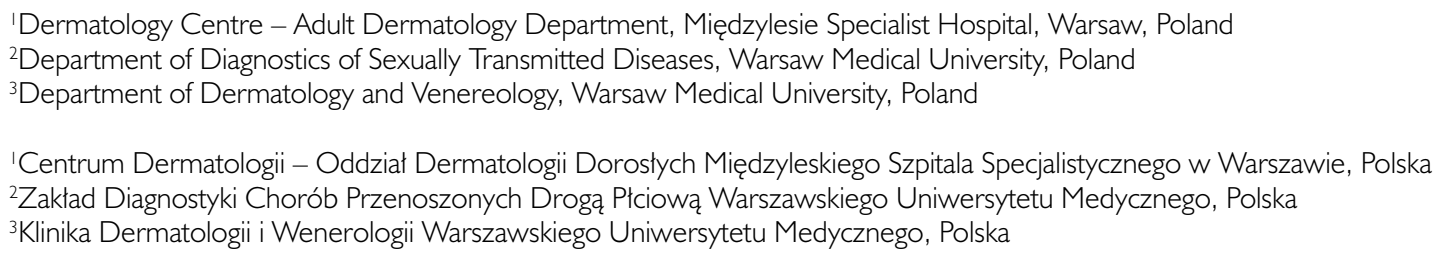

Dermatol Rev/Przegl Dermatol 2017, 104, 597-605 DOI: https://doi.org/I0.5। I4/dr.2017.7| 832

\section{CORRESPONDING AUTHOR/} ADRES DO KORESPONDENCJI: dr n. med. Beata Młynarczyk-Bonikowska

Zakład Diagnostyki

Chorób Przenoszonych

Drogą Płciową

Warszawski Uniwersytet

Medyczny

ul. Koszykowa 82 A

02-008 Warszawa, Polska

tel.: +48501533516

e-mail:

beata.mlynarczyk@wum.edu.pl

\begin{abstract}
Introduction. Syphilis is a sexually transmitted disease that can be asymptomatic or associated with various symptoms including systemic manifestations. A total of 1,253 cases of syphilis were registered in Poland in 2015. Syphilis frequently coexists with HIV infection and other sexually transmitted diseases.

Objective. Epidemiological and clinical characteristics of the population of patients treated for syphilis in the Department of Dermatology and Venereology, Medical University of Warsaw, and to evaluate the coexistence of other sexually transmitted diseases with special reference to HIV infection.
\end{abstract}

Material and methods. The retrospective study involved an analysis of information included in medical files of 411 consecutive patients treated for syphilis in the Department of Dermatology and Venereology, Medical University of Warsaw, in 2015.

Results. As many as $92 \%$ of the analyzed patients treated for syphilis were males, and $72.5 \%$ were men who have sex with men. Eighty-one percent of the subjects were between 21 and 40 years of age. Out of 325 patients with known HIV test results, $26.5 \%$ were HIV-positive. Evaluation of coexistence of other sexually transmitted diseases was difficult because of incomplete data, however gonorrhoea (7.8\%) and hepatitis C virus infection $(2.7 \%)$ were diagnosed more often in the studied group of patients with syphilis than in the general population. Hepatitis C virus infection was found in $6 \%$ of individuals co-infected with syphilis and HIV.

Conclusion. The results confirm the need to screen patients with syphilis for HIV infection, and HIV-positive patients for syphilis. 


\section{STRESZCZENIE}

Wprowadzenie. Kiła jest chorobą przenoszoną drogą płciową, która może przebiegać bezobjawowo lub wiązać się z występowaniem różnych objawów, w tym ogólnoustrojowych. W Polsce w 2015 r. zarejestrowano 1253 przypadki kiły. Kiła często współistnieje z zakażeniem HIV i z innymi chorobami przenoszonymi drogą płciową.

Cel pracy. Charakterystyka epidemiologiczna i kliniczna pacjentów leczonych z powodu kiły w Klinice Dermatologii i Wenerologii Warszawskiego Uniwersytetu Medycznego oraz ocena współistnienia innych chorób przenoszonych drogą płciową ze szczególnym uwzględnieniem zakażenia HIV.

Materiał i metodyka. W badaniu retrospektywnym przeanalizowano informacje zawarte $\mathrm{w}$ kolejnych historiach choroby 411 pacjentów Kliniki Dermatologii i Wenerologii Warszawskiego Uniwersytetu Medycznego leczonych z powodu kiły w 2015 r.

Wyniki. Spośród pacjentów leczonych z powodu kiły 92\% stanowili mężczyźni, a 72,5\% - mężczyźni mający kontakty z mężczyznami. Osiemdziesiąt jeden procent osób było między 21. a 40. rokiem życia. Spośród 325 osób o znanym wyniku badania w kierunku HIV 26,5\% było zakażonych HIV. Ocena współistnienia innych chorób przenoszonych drogą płciową była utrudniona ze względu na niepełne dane, jednak częściej niż w populacji ogólnej w badanej grupie występowała rzeżączka $(7,8 \%)$ oraz zakażenie wirusem zapalenia wątroby typu C (2,7\% chorych z kiłą). Zakażenie wirusem zapalenia wątroby typu C stwierdzono u $6 \%$ osób zakażonych jednocześnie kiłą i HIV.

Wnioski. Wyniki potwierdzają konieczność prowadzenia badań przesiewowych w kierunku zakażenia HIV u chorych z kiłą i w kierunku kiły u osób zakażonych HIV.

Key words: syphilis, epidemiology, sexually transmitted diseases, HIV infection.

Słowa kluczowe: kiła, epidemiologia, choroby przenoszone drogą płciową, zakażenie HIV.

\section{INTRODUCTION}

Syphilis is a sexually transmitted disease which occurs across the globe. According to the World Health Organisation (WHO) estimates, there were 5.6 million new cases of syphilis globally in 2012, including approximately 900,000 cases of syphilis among pregnant women [1]. Based on the data of the National Institute of Public Health - National Institute of Hygiene, a total of 1,253 syphilis cases were recorded in Poland in 2015, which corresponds to the incidence rate of approximately 3.2 per 100,000 population.

In a proportion of affected individuals, syphilis infection remains asymptomatic for a long period. In others, a variety of symptoms may occur depending on the duration of the disease. Primary stage syphilis usually lasts for 9 weeks after infection. It is characterized by the presence of a solitary ulcer or, less commonly, multiple ulcers on the genitals, accompa-

\section{WPROWADZENIE}

Kiła jest ogólnoustrojową chorobą przenoszoną drogą płciową, która występuje na całym świecie. Według szacunkowych danych Światowej Organizacji Zdrowia (World Health Organisation - WHO) w 2012 r. stwierdzono 5,6 miliona nowych przypadków kiły, w tym ok. 900 tysięcy dotyczyło kobiet w ciąży [1]. Na podstawie danych Narodowego Instytutu Zdrowia Publicznego - Państwowego Zakładu Higieny w 2015 r. w Polsce zarejestrowano 1253 przypadki kiły, co przekłada się na zachorowalność ok. 3,2 na 100 tysięcy ludności.

Zakażenie u części chorych przez długi czas jest bezobjawowe. U innych mogą występować różne objawy w zależności od czasu trwania choroby. Kiła pierwszego okresu trwa zwykle do 9. tygodnia od zakażenia. Charakteryzuje się obecnością pojedynczego owrzodzenia lub rzadziej mnogich owrzodzeń na na- 
nied by local lymph node enlargement. Symptoms of early secondary syphilis usually occur between 9 and 16 weeks after infection, and take the form of uniform, typically macular, rash located on the trunk and extremities. Secondary recurrent syphilis (between 16 weeks and 2 years after infection) may be manifested by a broad spectrum of symptoms including multiform skin eruptions - macular, papular or pustular rash, syphilitic ecthyma, overgrown papules in the anogenital area (so-called condylomata lata), as well as oral lesions, tonsilitis, hoarseness, alopecia, vitiligo and other abnormalities. Some patients with secondary syphilis also develop systemic symptoms such as subfebrile body temperature, malaise and generalized lymphadenopathy. Asymptomatic (latent) syphilis can be divided into early latent type up to two years after infection according to the WHO criteria and up to a year after infection according to the International Union against Sexually Transmitted Infections (IUSTI) and Centers for Disease Control and Prevention (CDC) criteria, and late latent syphilis - after that period. Untreated patients, usually after many years, may develop symptoms of late syphilis most typically affecting the central nervous system, less commonly cardiac or others. In pregnant women with syphilis there is a high risk of disease transfer to the foetus and newborn, leading to a number of complications including miscarriage, stillbirth and symptoms of congenital syphilis in the baby.

Syphilis frequently coexists with other sexually transmitted diseases and HIV infection, which is partially related to the same route and the same risk factors for infection. Similarly to the majority of other sexually transmitted diseases, syphilis may increase the risk of HIV transmission via sexual contacts. One of the published studies has found that the risk of HIV infection through heterosexual contact is five times higher in people who either have now, or have previously had, genital ulcers [2]. Apart from syphilis, other diseases which may present with genital ulcers include genital herpes.

In view of the frequent coexistence of other sexually transmitted diseases in patients with syphilis, CDC and IUSTI recommend screening for the diseases and, in particular, for HIV infection [3].

\section{OBJECTIVE}

The aims of the study were to characterize epidemiologically and clinically the population of patients treated for syphilis in the Department of Dermatology and Venereology, Medical University of Warsaw, and to evaluate the frequency of coexistence of other sexually transmitted diseases, especially HIV infection. rządach płciowych, którym towarzyszy powiększenie lokalnych węzłów chłonnych. Objawy kiły drugiego okresu wczesnej najczęściej występują między 9. a 16. tygodniem od zakażenia i mają charakter jednopostaciowej, zwykle plamistej osutki zlokalizowanej na tułowiu i kończynach. W przebiegu kiły drugiego okresu nawrotowej (od 16. tygodnia do 2 lat od zakażenia) może występować wiele różnych objawów, w tym wielopostaciowe zmiany na skórze - osutki plamiste, grudkowe lub krostkowe, niesztowice, przerosłe grudki w okolicy anogenitalnej, tzw. lepieże płaskie, zmiany w jamie ustnej, zapalenie migdałków, chrypka, łysienie, bielactwo. U części chorych z kiłą drugiego okresu pojawiają się objawy ogólne, np. stany podgorączkowe, złe samopoczucie, uogólnione powiększenie węzłów chłonnych. Kiłę bezobjawową (utajoną) można podzielić na: wczesną wg WHO do 2 lat od zakażenia, a wg the International Union against Sexually Transmitted Infections (IUSTI) i Centers for Disease Control and Prevention (CDC) do roku od zakażenia i późną powyżej tego okresu. U chorych nieleczonych, zwykle po wielu latach, mogą pojawić się objawy kiły późnej, najczęściej dotyczące ośrodkowego układu nerwowego, rzadziej kardiologiczne lub inne. Kiła u kobiet w ciąży z dużym prawdopodobieństwem przenosi się na płód i noworodka, co prowadzi do licznych powikłań, w tym poronienia, martwego porodu. U noworodka mogą wystąpić objawy kiły wrodzonej.

Kiła często współistnieje $\mathrm{z}$ innymi chorobami przenoszonymi drogą płciową oraz zakażeniem HIV. Ma to związek nie tylko z tą samą drogą i tymi samymi czynnikami ryzyka zakażenia. Kiła, podobnie jak większość innych chorób przenoszonych drogą płciową, może zwiększać ryzyko przenoszenia HIV poprzez kontakty seksualne. W jednym z badań stwierdzono, że ryzyko nabycia zakażenia HIV przez kontakt heteroseksualny jest 5 razy większe u osób, które aktualnie lub w przeszłości miały owrzodzenia na narządach płciowych [2]. Do chorób, które mogą wiązać się z owrzodzeniami w okolicy genitalnej, oprócz kiły, zalicza się także opryszczkę narządów płciowych.

Ze względu na częste współwystępowanie innych chorób przenoszonych drogą płciową u chorych z kiłą CDC i IUSTI zalecają badania przesiewowe w kierunku tych chorób, zwłaszcza badanie w kierunku zakażenia HIV [3].

\section{CEL PRACY}

Celem pracy była charakterystyka epidemiologiczna i kliniczna pacjentów leczonych z powodu kiły w Klinice Dermatologii i Wenerologii Warszawskiego Uniwersytetu Medycznego oraz ocena częstości współistnienia innych chorób przenoszonych 


\section{MATERIAL AND METHODS}

The retrospective study included 411 patients treated for syphilis in the Department of Dermatology and Venereology, Medical University of Warsaw, in 2015. The medical histories of consecutive patients with syphilis were analyzed without applying any additional study inclusion or exclusion criteria. All patients with syphilis who had not been previously diagnosed with HIV infection and gave their consent were tested for HIV. Gonorrhoea and chlamydia screening was performed only when patients with syphilis or their partners had clinical symptoms consistent with these infections. Genital herpes and venereal warts were diagnosed on the basis of clinical manifestations. Since there was no possibility to perform screening for hepatitis $C$ virus (HCV) infection in all the patients, the analysis was based mainly on information and results of tests conducted at other medical centres and supplied by the patients.

\section{RESULTS}

Men (379) represented $92 \%$ of the patients diagnosed with syphilis, with $72.5 \%$ (298) declaring sexual contacts with men (MSM), including 245 homosexuals and 53 bisexuals. The remaining 81 men reported being heterosexual in the medical interview. Only 32 women ( $8 \%$ of all treated patients), including 3 pregnant women, were treated for syphilis during the study period. The incidence rate of syphilis by sex and sexual orientation is shown in figure 1 . The age range in the study group was $18-74$ years, and the mean age was 34 years. The most common age at diagnosis was between 21 and 40 years (in $81 \%$ of all cases).

Out of 325 subjects with known HIV test results, $80(26.5 \%)$, including 70 MSM, were HIV-positive. In $32(40 \%)$ cases, HIV was diagnosed at approximately the same time as syphilis. In the remaining patients the diagnosis of HIV infection preceded that of syphilis. A total of 86 patients refused to be tested for HIV in our medical centre. With respect to other sexually transmitted diseases, 32 subjects (approximately 7.8\%) were diagnosed with gonorrhoea, 19 with venereal warts/symptomatic HPV infection $(4.6 \%), 15$ with genital herpes $(3.6 \%)$, 11 with HCV infection $(2.7 \%)$ and 5 with Chlamydia trachomatis infection $(1.2 \%)$. The coexistence of sexually transmitted diseases in patients with syphilis is shown in figure 2 .

In the subset of patients infected with both syphilis and HIV, gonorrhoea was found in $8 \%$, venereal warts in $6 \%$, genital herpes in $3 \%$ and $\mathrm{HCV}$ infection in $6 \%$. The coexistence of sexually transmitted dis- drogą płciową ze szczególnym uwzględnieniem zakażeń HIV.

\section{MATERIAŁ I METODYKA}

Do retrospektywnego badania włączono 411 pacjentów Kliniki Dermatologii i Wenerologii Warszawskiego Uniwersytetu Medycznego leczonych z powodu kiły w $2015 \mathrm{r}$. Analizowano historie choroby kolejnych pacjentów z kiłą, nie stosując dodatkowych kryteriów wyłączenia lub włączenia do badania. Wszyscy pacjenci z kiłą, którzy nie mieli wcześniej rozpoznanego zakażenia HIV oraz wyrazili zgodę na badanie, byli badani w kierunku zakażenia HIV. Badania w kierunku rzeżączki i chlamydiozy wykonywano tylko, gdy u pacjenta z kiłą lub jego partnera występowały objawy kliniczne sugerujące te zakażenia. Opryszczkę narządów płciowych i kłykciny kończyste rozpoznawano na podstawie objawów klinicznych. Ze względu na brak możliwości nie przeprowadzono u wszystkich chorych badań przesiewowych w kierunku zakażenia wirusem zapalenia wątroby typu C (hepatitis C virus - HCV), a oparto się głównie na dostarczonych przez pacjentów danych i wynikach badań z innych ośrodków.

\section{WYNIKI}

Mężczyźni stanowili 92\% (379) chorych z rozpoznaniem kiły, 72,5\% (298) deklarowało kontakty seksualne z mężczyznami (MSM), w tym było 245 pacjentów o orientacji homoseksualnej i 53 biseksualistów. Pozostałych 81 mężczyzn podawało w wywiadzie orientację heteroseksualną. W badanym okresie leczono z powodu kiły zaledwie 32 kobiety ( $8 \%$ wszystkich badanych), w tym 3 kobiety w ciąży. Występowanie kiły $\mathrm{w}$ zależności od płci i orientacji seksualnej przedstawiono na rycinie 1 . Przedział wiekowy badanej grupy to 18-74 lata, a średnia wieku 34 lata. Najczęściej chorobę rozpoznawano u osób między 21. a 40. rokiem życia (81\% przypadków).

Spośród 325 osób, u których znane były wyniki badania w kierunku HIV, 80 (26,5\%), w tym 70 MSM, było zakażonych wirusem HIV. W 32 (40\%) przypadkach infekcji HIV i kiłę zdiagnozowano w zbliżonym czasie. U pozostałych pacjentów zakażenie HIV rozpoznano wcześniej niż kiłę. Osiemdziesiąt sześć osób nie zgodziło się na badanie HIV w naszej placówce. Z innych chorób przenoszonych drogą płciową u 32 badanych (ok. 7,8\%) rozpoznano rzeżączkę, u 19 kłykciny kończyste lub objawowe zakażenie wirusem brodawczaka ludzkiego (HPV; 4,6\%), u 15 opryszczkę narządów płciowych $(3,6 \%)$, u 11 zakażenie $\mathrm{HCV}$ $(2,7 \%)$ i u 5 zakażenie Chlamydia trachomatis $(1,2 \%)$. Współwystępowanie chorób przenoszonych drogą płciową u pacjentów z kiłą przedstawiono na rycinie 2 . 

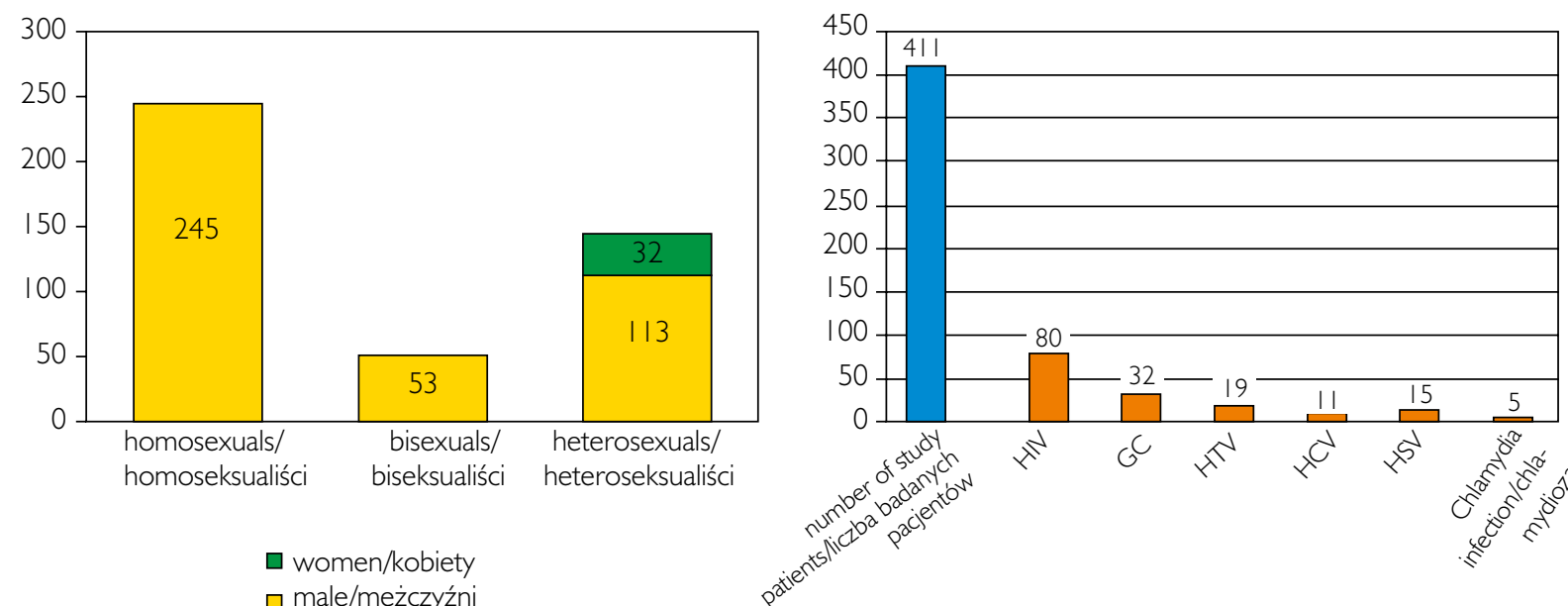

$\square$ women/kobiety

GC - rzeżq̨czka, HPV - kłykciny kończyste, HCV - zakażenie wirusem zapalenia wątroby typu C, HSV - opryszczka narządów płciowych.

Figure I. Structure of the study group by sex and sexual preferences

Rycina I. Podział badanej grupy wg płci i preferencji seksualnych

GC - gonorrhoea, HPV - venereal warts, HCV - hepatitis C virus infection, HSV - genital herpes.

Figure 2. Sexually transmitted diseases coexisting with syphilis

Rycina 2. Choroby przenoszone drogq ptciowq wspótistniejące z kiłq

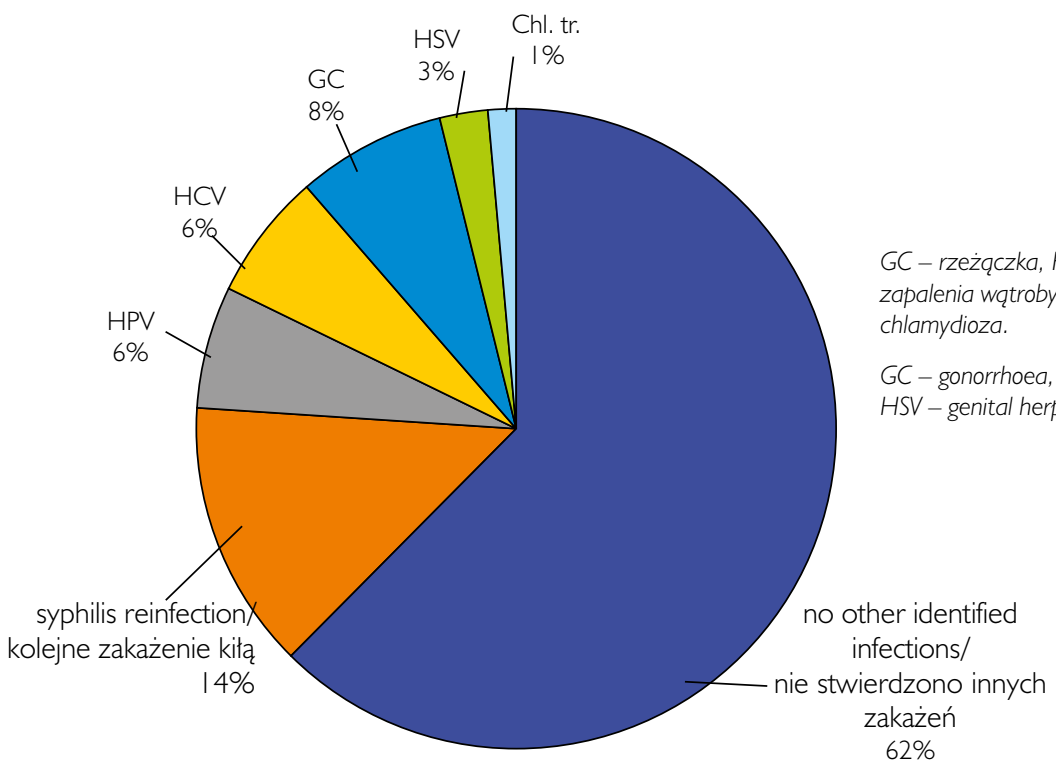

Figure 3. Coexistence of sexually transmitted infections in patients with syphilis and HIV

Rycina 3. Wspótistnienie zakażeń przenoszonych droga płciowq u pacjentów z kita i HIV

eases in patients with syphilis and HIV is shown in figure 3.

A total of 312 patients were diagnosed with early syphilis, including 61 with primary syphilis, 200 with secondary syphilis (including 23 with early secondary syphilis), and 51 patients with early latent syphilis. Primary syphilitic lesions were located mainly on the genitals (54 subjects) and much less commonly in the anal area (6 subjects) or in the oral cavity (1 subject). Late syphilis was diagnosed in just 1 patient during the study period, however the group of patients with latent syphilis of unspecified time of infection was relatively large (98 subjects).
W przypadku osób jednocześnie zakażonych kiłą i HIV rzeżączkę stwierdzono u 8\%, kłykciny kończyste u $6 \%$, opryszczkę narządów płciowych u $3 \%$, a zakażenie HCV u 6\%. Współistnienie chorób przenoszonych drogą płciową u chorych z kiłą i HIV przedstawiono na rycinie 3 .

U 312 chorych rozpoznano kiłę wczesną, w tym u 61 kiłę pierwszego okresu, u 200 - kiłę drugiego okresu (w tym u 23 kiłę drugiego okresu wczesną), u 51 kiłę wczesną utajoną. Kiłowe objawy pierwotne były umiejscowione zwykle na narządach płciowych (u 54 osób), a znacznie rzadziej w okolicy odbytu (6 osób) lub w jamie ustnej (1 osoba). Kiłę późną roz- 


\section{DISCUSSION}

In 2015, a total of 486 new cases of syphilis were recorded in the Mazovia Province. Approximately $98 \%$ of these patients received treatment in the outpatient clinic at the Department of Dermatology and Venereology, Medical University of Warsaw.

Our study found a higher prevalence of syphilis in men, particularly MSM, in the study group. The coexistence of HIV infection was also considerably more common than in the general population (the prevalence of HIV in the Polish population is estimated by the WHO at $0.1-0.3 \%)$. As it was not possible to perform screening tests in all patients with syphilis presenting to our outpatient clinic, data on the coexistence of other sexually transmitted diseases may be incomplete. Furthermore, the lack of reliable epidemiological data on the coexistence of the diseases in the general population, resulting from their underreporting in Poland, makes comparisons quite difficult. Based on the available data, however, it can be presumed that gonorrhoea is much more common in patients with syphilis than in the general population. Studies conducted in other medical centres have also provided evidence for the frequent coexistence of both diseases [4-6]. In addition, syphilis seems to coexist with other sexually transmitted diseases, particularly HCV infection, more frequently (according to estimates, approximately $0.6 \%$ of Polish inhabitants are infected with HCV) [7].

A number of studies conducted in various countries have produced similar results to ours. In the study involving 175 patients with early syphilis from 3 medical centres in Poland, Germany and Ireland, a total of $86.3 \%$ of the subjects were MSM and as many as $68 \%$ were HIV-positive (a higher rate than in our study). The majority of HIV-positive patients were diagnosed with secondary syphilis $(55.7 \%$ vs. $13.2 \%)(p=0.0001)$. Primary syphilis was more common in HIV-negative patients (47.2\% vs. $18.9 \%$, $p=0.0002)$. The coexistence of other sexually transmitted diseases was found in $26.8 \%$ of the subjects [8]

A total of 6,834 syphilis infections were recorded in Germany in 2015, of which $85 \%$ were diagnosed in MSM. In $6.3 \%$ of patients, an optional screening test revealed HIV infection coexisting with syphilis. Approximately 57\% of HIV-infected individuals in Germany in 2015 were estimated to be MSM [9].

A study conducted in Spain in 2011-2015 in 220 patients with syphilis showed that $98 \%$ of them were men (including 94\% MSM). The HIV infection rate was $62 \%$ [10]. In a retrospective study conducted in Barcelona in 2007-2011, 66.8\% of HIV cases, $74.2 \%$ of syphilis cases, $45 \%$ of gonorrhoea cases and $95.7 \%$ of lymphogranuloma venereum cases were attributed to the MSM group [4]. poznano w badanym okresie zaledwie u 1 pacjenta, jednak stosunkowo duża była grupa chorych z kiłą utajoną o nieokreślonym czasie zakażenia (98 osób).

\section{OMÓWIENIE}

W województwie mazowieckim w 2015 r. zarejestrowano 486 nowych przypadków kiły. Około $98 \%$ pacjentów było leczonych w Klinice Dermatologii i Wenerologii Warszawskiego Uniwersytetu Medycznego.

W badanej grupie wykazano częstsze występowanie kiły u mężczyzn, zwłaszcza u MSM. Zakażenie HIV stwierdzano znacznie częściej niż w populacji ogólnej (odsetek osób zakażonych HIV wg danych WHO w populacji polskiej szacuje się na 0,1-0,3\%). Ze względu na brak możliwości przeprowadzenia przez autorów badań przesiewowych u wszystkich zgłaszających się do poradni chorych $\mathrm{z}$ kiłą dane dotyczące współwystępowania innych chorób przenoszonych drogą płciową mogą być niepełne. Ponadto uniemożliwia porównanie brak wiarygodnych danych epidemiologicznych dotyczących występowania tych chorób w populacji ogólnej wynikający z ich niewystarczającej zgłaszalności w Polsce. Na podstawie dostępnych danych można jednak przypuszczać, że rzeżączka jest znacznie częstsza u osób z kiłą niż w populacji ogólnej. W badaniach w innych ośrodkach również stwierdzono częste współistnienie tych dwóch chorób [4-6]. Wydaje się również, że kiła częściej współistnieje z pozostałymi chorobami przenoszonymi drogą płciową, zwłaszcza z zakażeniem HCV (szacuje się, że ok. 0,6\% osób w Polsce jest zakażonych tym wirusem) [7].

W wielu badaniach przeprowadzanych w różnych krajach uzyskano wyniki zbliżone do naszych. W badaniu dotyczącym 175 pacjentów z kiłą wczesną z 3 ośrodków w Polsce, Niemczech i Irlandii wykazano, że $86,3 \%$ badanych było MSM, a aż $68 \%$ było zakażonych HIV (wyższy odsetek niż w naszym badaniu). U większości chorych z infekcją HIV rozpoznano kiłę drugiego okresu w odróżnieniu od pacjentów, u których nie stwierdzono tej infekcji (odpowiednio 55,7\% i 13,2\%) $(p=0,0001)$. Kiła pierwszego okresu występowała częściej u osób bez infekcji HIV niż u zakażonych HIV (odpowiednio 47,2\% i 18,9\%) ( $p=0,0002$ ). Inne choroby przenoszone drogą płciową współwystępowały u 26,8\% badanych [8]

W Niemczech w 2015 r. zarejestrowano 6834 przypadki kiły, ok. $85 \%$ spośród nich dotyczyło MSM. U 6,3\% chorych wraz z kiłą wykryto zakażenie HIV w ramach opcjonalnego testu przesiewowego. Szacuje się, że ok. 57\% osób zakażonych HIV w Niemczech w 2015 r. to MSM [9].

W badaniu przeprowadzonym w Hiszpanii w latach 2011-2015 u 220 pacjentów z kiłą wykazano, że 98\% z nich stanowią mężczyźni (w tym 94\% MSM). Odsetek osób zakażonych HIV wynosił 62\% [10]. W badaniu re- 
A study conducted in a large group of MSM (85,500 in total) presenting to sexually transmitted infection (STI) clinics in United Kingdom demonstrated a higher risk of HIV infection in individuals diagnosed with syphilis or gonorrhoea within the preceding year. The adjusted hazard ratio was 4.1 (95\% CI: 2.0-8.3) and 2.1 (95\% CI: 1.4-3.2) for syphilis and gonorrhoea, respectively [11]. Other studies conducted in the British population have found that nearly $79 \%$ of all syphilis cases and $58 \%$ of gonorrhoea diagnosed in 2012 were in the MSM group. Approximately $1 / 3$ of MSM diagnosed with syphilis in the UK were HIV-positive [6].

A study encompassing a large group of MSM in the Netherlands showed that $12.3 \%$ of HIV-positive patients in 2007 and $4.5 \%$ in 2011 were seropositive for syphilis. Among HIV-negative MSM, the values were $2.8 \%$ and $1.4 \%$ in 2007 and 2011, respectively [12].

Based on the CDC data, $81.7 \%$ of cases of early symptomatic syphilis recorded in men in 2015 in the USA, where the sex of the partner could be established, were in the MSM group. A large questionnaire study encompassing 28,295 sexually active MSM from 20 cities across the USA in 2008-2014 showed that $40 \%$ of the respondents in 2008 and over $49 \%$ of the respondents in 2014 were screened for syphilis. Syphilis seropositivity was established in approximately $21 \%$ and $8 \%$ of MSM declaring themselves as HIV-positive and HIV-negative, respectively, which shows that the frequency of coexistence of both diseases is higher in a statistically significant manner [13]. Studies conducted in Florida in 2010 demonstrated that $42 \%$ of patients with syphilis were HIV-positive [5]. Other US studies found that the probability of syphilis and HIV infection diagnosis was over 140 times higher in the MSM population than in heterosexual men [14].

A study investigating the prevalence and coexistence of sexually transmitted diseases in MSM in Peru demonstrated syphilis in $16.8 \%$ and coexisting HIV infection in $44.2 \%$ of 312 men included in the study [15].

The prevalence of HIV and syphilis co-infection has also been studied in 533 MSM in China. The study found HIV in $24.2 \%(129 / 533)$, syphilis in $29.8 \%(159 / 533)$ and both infections in $13.13 \%$ $(70 / 533)$ of the subjects. HIV co-infection was thus present in approximately $44 \%$ of patients with syphilis [16].

The variability of results obtained by various authors may be attributed to differences in the prevalence of both diseases in various geographical regions and variation in study populations. trospektywnym przeprowadzonym w Barcelonie w latach 2007-2011 66,8\% przypadków z zakażeniem HIV, 74,2\% z kiłą, $45 \%$ z rzeżączką oraz $95,7 \%$ przypadków ziarnicy wenerycznej pachwin dotyczyło grupy MSM [4].

Badanie przeprowadzone $\mathrm{w}$ dużej grupie MSM (85 500 osób) zgłaszających się do klinik chorób przenoszonych drogą płciową w Wielkiej Brytanii wykazało większe prawdopodobieństwo zakażenia HIV u osób $z$ rozpoznaniem kiły lub rzeżączki $w$ ostatnim roku przed ewentualnym rozpoznaniem zakażenia HIV. Skorygowany współczynnik ryzyka wynosił odpowiednio 4,1 (95\% CI: 2,0-8,3) i 2,1 (95\% CI: 1,4-3,2) dla kiły i rzeżączki [11]. W innych badaniach w populacji brytyjskiej stwierdzono, że w 2012 r. ok. 79\% wszystkich przypadków kiły i $58 \%$ przypadków rzeżączki dotyczyło MSM. Około 1/3 MSM z rozpoznaniem kiły w Wielkiej Brytanii było zakażonych HIV [6].

$\mathrm{W}$ badaniu przeprowadzonym $\mathrm{w}$ dużej grupie MSM w Holandii wykazano, że 12,3\% zakażonych HIV w 2007 r. i 4,5\% w 2011 r. miało dodatni wynik badania serologicznego w kierunku kiły. Wśród MSM niezakażonych HIV wartości te wynosiły odpowiednio 2,8\% i 1,4\% w latach 2007 i 2011 [12].

Według CDC w 2015 r. w Stanach Zjednoczonych 81,7\% przypadków kiły wczesnej objawowej u mężczyzn, w których udało się ustalić płeć partnera, dotyczyło grupy MSM. W dużym badaniu ankietowym przeprowadzonym w latach 2008-2014 i dotyczącym 28295 aktywnych seksualnie MSM mieszkajacych w 20 różnych miastach w Stanach Zjednoczonych wykazano, że $40 \%$ ankietowanych w 2008 r. i ponad $49 \%$ w 2014 r. badało się przesiewowo w kierunku kiły. Dodatni wynik badania serologicznego w kierunku kiły uzyskało ok. 21\% MSM deklarujących się jako HIV-pozytywnych i $8 \%$ HIV-negatywnych, co potwierdza istotnie statystycznie częstsze współistnienie tych dwóch chorób [13]. W badaniach przeprowadzonych na Florydzie w 2010 r. stwierdzono, że $42 \%$ osób z kiłą było zakażonych HIV [5]. Inne badania w Stanach Zjednoczonych wykazały, że prawdopodobieństwo rozpoznania kiły i zakażenia HIV było w grupie MSM aż ponad 140 razy większe niż u mężczyzn heteroseksualnych [14].

W badaniu oceniającym występowanie i współistnienie chorób przenoszonych drogą płciową u MSM w Peru stwierdzono, że 16,8\% spośród 312 badanych mężczyzn było zakażonych kiłą, a zakażenie HIV współistniało w $44,2 \%$ przypadków [15].

Występowanie kiły i zakażenia HIV badano u 533 MSM w Chinach. Zakażenie HIV stwierdzono u 24,2\% (129/533) pacjentów, kiłę u 29,8\% (159/533), a oba zakażenia jednocześnie u 13,13\% (70/533). Zakażenie HIV wspólistniało u ok. 44\% chorych z kiłą [16].

Różnice w wynikach uzyskanych przez różnych autorów mogą wynikać $\mathrm{z}$ różnej częstości występowania powyższych chorób w różnych obszarach geograficznych i w różnych populacjach. 


\section{CONCLUSIONS}

Out retrospective study shows that syphilis in $\mathrm{Po}$ land, similarly to many other countries, occurs more frequently in men, and is particularly common in the group of MSM. Screening tests in Poland are conducted primarily in pregnant women, which is perfectly justified, however it appears that screening and other preventative measures should have more widespread use in the MSM population and, as the next step, also in men having frequent casual heterosexual encounters.

We have shown that the proportion of HIV-infected individuals in the study group of patients with syphilis $(26.5 \%)$ is markedly higher than in the general population. Similar or higher rates of coexistence of both diseases have been described in the international literature.

It is alarming to note that there is a relatively large group of people who, despite their awareness of HIV infection, engage in high-risk sexual behaviour and become infected with syphilis (60\% of all HIV-positive patients in our study group).

Both IUSTI and CDC recommend screening for HIV in every patient with syphilis, as well as periodic screening tests for syphilis in HIV-positive patients. The above data obtained in the Polish population validate this need.

\section{CONFLICT OF INTEREST}

The authors declare no conflict of interest.

\section{WNIOSKI}

Przeprowadzone przez nas badanie retrospektywne wykazało, że w Polsce kiła, podobnie jak w wielu innych krajach, częściej występuje u mężczyzn, szczególnie często u MSM. Prowadzone w Polsce badania przesiewowe, co ma pełne uzasadnienie, dotyczą głównie kobiet $\mathrm{w}$ ciąży. Wydaje się jednak, że tego typu badania oraz inne działania profilaktyczne należałoby przeprowadzać również w grupie MSM, a także u mężczyzn mających liczne przygodne kontakty heteroseksualne.

Jak wykazano, odsetek osób zakażonych HIV wśród badanych przez nas chorych na kiłę (26,5\%) jest znacznie większy niż w populacji ogólnej w Polsce, w której wynosi $0,1-0,4 \%$. Podobny lub wyższy odsetek wspótistnienia tych dwóch chorób opisano w światowym piśmiennictwie.

Niepokojący jest fakt, że istnieje stosunkowo duża grupa osób, które mimo iż są świadome zakażenia HIV, podejmują ryzykowne kontakty seksualne i zakażają się kiłą (w badanej przez nas grupie $60 \%$ wszystkich pacjentów zakażonych HIV).

IUSTI i CDC rekomendują wykonywanie badania w kierunku HIV u każdego chorego na kiłę, a także okresowych przesiewowych badań w kierunku kiły u pacjentów zakażonych HIV. Powyższe dane uzyskane w polskiej populacji potwierdzają taką konieczność.

\section{KONFLIKT INTERESÓW}

Autorzy deklarują brak konfliktu interesów.

\section{References}

\section{Piśmiennictwo}

1. Newman L., Rowley J., Vander Hoorn S., Wijesooriya N.S., Unemo M., Low N., et al.: Global estimates of the prevalence and incidence of four curable sexually transmitted infections in 2012 based on systematic review and global reporting. PLoS One 2015, 10, e0143304.

2. Boily M.C., Baggaley R.F., Wang L., Masse B., White R.G., Hayes R.J., et al.: Heterosexual risk of HIV-1 infection per sexual act: systematic review and meta-analysis of observational studies. Lancet Infect Dis 2009, 9, 118-129.

3. Workowski K.A., Bolan G.A.: Centers for Disease Control and Prevention Sexually transmitted diseases treatment guidelines 2015. MMWR Recomm Rep 2015, 5, 1-137.

4. Martí-Pastor M., García de Olalla P., Barberá M.J., Manzardo C., Ocaña I., Knobel H., et al.: Epidemiology of infections by HIV, syphilis, gonorrhea and lymphogranuloma venereum in Barcelona city: a population-based incidence study. BMC Public Health 2015, 15, 1015.

5. Centers for Disease Control and Prevention: Sexually Transmitted Disease Surveillance, 2015. U.S Department of Health and Human Services Centers for Disease Control and Prevention National Center for HIV/AIDS, Viral Hepatitis, STD, and TB Prevention Division of STD Prevention Atlanta, Georgia.

6. Hughes G., Field N.: The epidemiology of sexually transmitted infections in the UK: impact of behavior, services and interventions. Future Microbiol 2015, 10, 35-51.

7. Flisiak R., Halota W., Horban A., Juszczyk J., Pawlowska M., Simon K.: Prevalence and risk factors of HCV infection in Poland. Eur J Gastroenterol Hepatol 2011, 23, 1213-1217.

8. Rowley D., Swięcki P., Firlag-Burkacka E., Sabin C., Kümmerle T., Surah S., et al.: Clinical and epidemiological characteristics of patients with early syphilis from three academic centres in Poland, Germany and Ireland: initial findings from the POETS study. Sex Transm Infect 2015, 91, 389-394.

9. Bremer V., Dudareva-Vizule S., Buder S., An der Heiden M., Jansen K.: Sexually transmitted infections in Germany: the current epidemiological situation. Bundesgesundheitsblatt Gesundheitsforschung Gesundheitsschutz 2017, doi: 10.1007/s00103017-2590-1. 
10. Fustà X., Fuertes I., Lugo-Colón R., Blanco J.L., Baras N., Alsina-Gibert M.: Syphilis epidemics: a descriptive study of patients diagnosed in a tertiary hospital between 2011 and 2015. Med Clin (Barc) 2017, pii: S0025-7753(17)30363-9.

11. Desai S., Nardone A., Hughes G., Delpech V., Burns F., Hart G., et al.: HIV incidence in an open national cohort of men who have sex with men attending sexually transmitted infection clinics in England. HIV Med 2017, 18, 615-622.

12. van Aar F., den Daas C., van der Sande M.A., Soetens L.C., de Vries H.J., van Benthem B.H.: Outbreaks of syphilis among men who have sex with men attending STI clinics between 2007 and 2015 in the Netherlands: a space-time clustering study. Sex Transm Infect 2017, 93, 390-395.

13. An Q., Wejnert C., Bernstein K., Paz-Bailey G.; NHBS Study Group: Syphilis screening and diagnosis among men who have sex with men, 2008-2014, 20 U.S. Cities. J Acquir Immune Defic Syndr 2017, 75, S363-S369.

14. Pathela P., Braunstein S.L., Schillinger J.A., Shepard C., Sweeney M., Blank S.: Men who have sex with men have a 140-fold higher risk for newly diagnosed HIV and syphilis compared with heterosexual men in New York City. J Acquir Immune Defic Syndr 2011, 58, 408-416.

15. Kojima N., Park H., Konda K.A., Joseph Davey D.L., Bristow C.C., Brown B., et al.: The PICASSO Cohort: baseline characteristics of a cohort of men who have sex with men and male-to-female transgender women at high risk for syphilis infection in Lima, Peru. BMC Infect Dis 2017, 17, 255.

16. Dai W., Luo Z., Xu R., Zhao G., Tu D., Yang L., et al.: Prevalence of HIV and syphilis co-infection and associated factors among non-commercial men who have sex with men attending a sexually transmitted disease clinic in Shenzhen, China. BMC Infect Dis $2017,17,86$.

Received: 6.09 .2017

Accepted: 3.10 .2017

Otrzymano: 6.09.2017 r.

Zaakceptowano: $3.10 .2017 \mathrm{r}$.

How to cite this article

Biało-Wójcicka E., Młynarczyk-Bonikowska B., Winiarska A., Rudnicka I., Pniewski T., Komorowska A., Malejczyk M., Majewski S.: Syphilis in patients of the Department of Dermatology and Venereology at Medical University of Warsaw in 2015 - epidemiological and clinical characteristics, and coexistence of other sexually transmitted diseases. Dermatol Rev/Przegl Dermatol 2017, 104, 597-605. DOI: https://doi.org/10.5114/dr.2017.71832. 